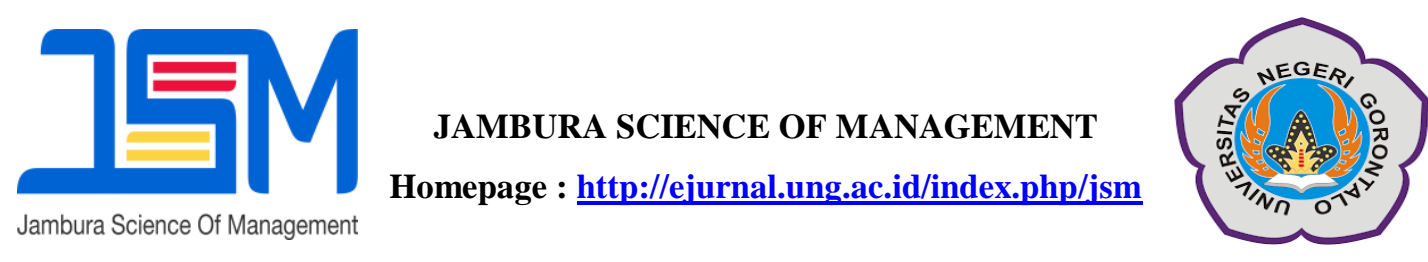

\title{
Factors Affecting The Level Of Financial Literation In College Student
}

\author{
Havea Prama Silta ${ }^{1}$ Ida Miharti ${ }^{2}$ \\ ${ }^{1,2}$ Economic Faculty, Andalas University \\ E-mail: Haveaprama@gmail.com
}

\begin{abstract}
:
This research is conducted to obtain empirical evidence that there are influences on financial literacy. The sample used in this research is college student in Faculty of Economic Andalas University. A regression analysis is used to test the hypothesis. Hypothetical test results show that there are no influences of gender, department, parent's income and parent's education on financial literacy, but only the year entry has an influence on financial literacy.
\end{abstract}

\section{Keywords: Financial Literacy, Sex, Program Study, Year Entry, Parent's Income, Parent's} Education.

In the modern era, people tend to behave extravagantly. This is due to the lack of public knowledge of financial understanding. Therefore, financial literacy is a basic need for everyone to avoid financial problems. Financial literacy is used in connection with certain personal finance matters such as real estate, insurance, investment, savings, tax planning and pensions and involves indepth financial knowledge such as compound interest, financial planning, credit card mechanisms, time value of money, etc. . In fact, financial literacy in Indonesia is arguably weak. Based on the Financial Services Authority (OJK) research, financial literacy is an important part for a country to improve its economy. A survey conducted by OJK (OJK, 2013) states that the level of financial literacy of the Indonesian population is divided into 4 parts: well literate $(21.84 \%)$, sufficient literate $(75.69 \%)$, less literate $(2.06 \%)$, not literate $(0.41 \%)$. From the survey, the level of financial literacy in Indonesia itself has a low level of literacy compared to neighboring countries. Financial literacy in Malaysia has reached $66 \%$, Singapore has reached $98 \%$, while Thailand has reached 73\% (Siregar, 2013).

OJK itself is targeting that by 2019 the level of public understanding of the financial system in Indonesia will increase by $75 \%$. To achieve these targets various programs are carried out in the form of; cooperating with partners such as banks and financial service institutions to provide the whole understanding to the community (Afrianto, 2016). The education program continues to be intensively carried out to 
the community, but this is not easy to implement. Especially if people who do not have a basic education and also a different level of education that allows the results of different levels of financial literacy in the community. The level of education is usually directly proportional to the level of financial literacy, in other words if the level of education is low then the level of literacy is also low, and vice versa (Nidar and Bestari, 2012).

As one part of the community which is classified as highly educated, students should have a good literacy level. However, the current phenomenon does not reflect that students have a good level of financial literacy. This can be seen from the financial behavior and priorities in the economy. They live in a consumptive manner without considering what they need rather than what they want (Mandell and Klein, 2009). They have a limited level of savings because they are still in the hands of their parents. In other words, they are still given monthly money which must be managed well. The surrounding environment or more specifically the current association has an impact on financial management and the consumptive nature of students. If without good financial literacy, they could be mistaken in managing financial resources and the difficulty of achieving prosperity.

Many factors can affect a person's level of financial literacy, including: gender, study program, year of entry, parents 'monthly income, and parents' level of education. Gender influences financial literacy, women tend to be less interested in participating in the stock market than men, women are more educated than men, while men have higher incomes than women (Almenberg and Dreber, 2015). Study programs have an influence on financial literacy because students with economic studies have higher literacy rates than students with non-economic study programs (Khrisna, et. Al., 2010). Entrance year has an influence on financial literacy, because new students have lower financial literacy compared to senior students because senior students already have more financial knowledge related to new students (Shaari, et. Al., 2013). Parental income level has an influence on financial literacy, because the level of parental income is an important indicator for the overall daily life of students because parents with limited income have less financial literacy on certain topics, such as savings, investments, managing portfolios due lack of surplus funds needed to do this (Altintas, 2011). The level of education of parents has an influence on financial literacy, because highly educated parents have more attention to their children and are more interested in their children being accepted at universities (Altintas, 2011).

\section{METHOD}

This study uses a questionnaire data collection technique, which is a list of pre-formulated written questions that the respondent will answer, usually in clearly defined alternatives (Sekaran, 2006). Data is also collected by the documentation 
method obtained from books, journals, and browsing through the internet. The population in this study were active students in 2013-2016, Faculty of
1,956 people. The sample was determined using the Slovin formula and obtained 332 respondents. The description of variables can be seen in the following table;

Economics, Andalas University, totaling

Table 1. Definition of Variable Operations

\begin{tabular}{|c|c|c|c|c|}
\hline No. & Variable & Definition & Indicator & Scale \\
\hline 1. & Dependent: & & & \\
\hline A. & Financial Literacy & $\begin{array}{l}\text { The ability to use } \\
\text { knowledge and skills to } \\
\text { manage financial } \\
\text { resources effectively to } \\
\text { achieve financial } \\
\text { prosperity (Kaur, et. al., } \\
\text { 2015). }\end{array}$ & $\begin{array}{l}\text { 1. } \begin{array}{l}\text { Personal } \\
\text { financial } \\
\text { management }\end{array} \\
\text { 2. } \begin{array}{l}\text { Financial } \\
\text { concept }\end{array} \\
\text { 3. } \begin{array}{l}\text { Economic } \\
\text { concept }\end{array} \\
\text { 4. Capital } \\
\text { market } \\
\text { 5. Investment } \\
\text { 6. Banking } \\
\text { service } \\
\text { 7. Financial } \\
\text { knowledge } \\
\text { 8. Insurance } \\
\text { 9. International } \\
\text { finance } \\
\text { 10. tax }\end{array}$ & Ordinal \\
\hline 2. & Independent: & & & \\
\hline A. & Gender & $\begin{array}{l}\text { A concept that } \\
\text { distinguishes between } \\
\text { men and women in } \\
\text { behavior (Hungu, } \\
\text { 2007). }\end{array}$ & $\begin{array}{ll}\text { 1. } & \text { Male } \\
\text { 2. } & \text { Female }\end{array}$ & Nominal \\
\hline B. & Department & $\begin{array}{l}\text { The unity of learning } \\
\text { plans as guidelines for } \\
\text { the administration of } \\
\text { education, academics } \\
\text { which are held on the } \\
\text { basis of a curriculum } \\
\text { and is intended so that } \\
\text { students can master } \\
\text { knowledge, skills and } \\
\text { attitudes in accordance } \\
\text { with curriculum }\end{array}$ & $\begin{array}{l}\text { 1. Management } \\
\text { 2. Accounting } \\
\text { 3. Economic } \\
\text { development }\end{array}$ & Nominal \\
\hline
\end{tabular}




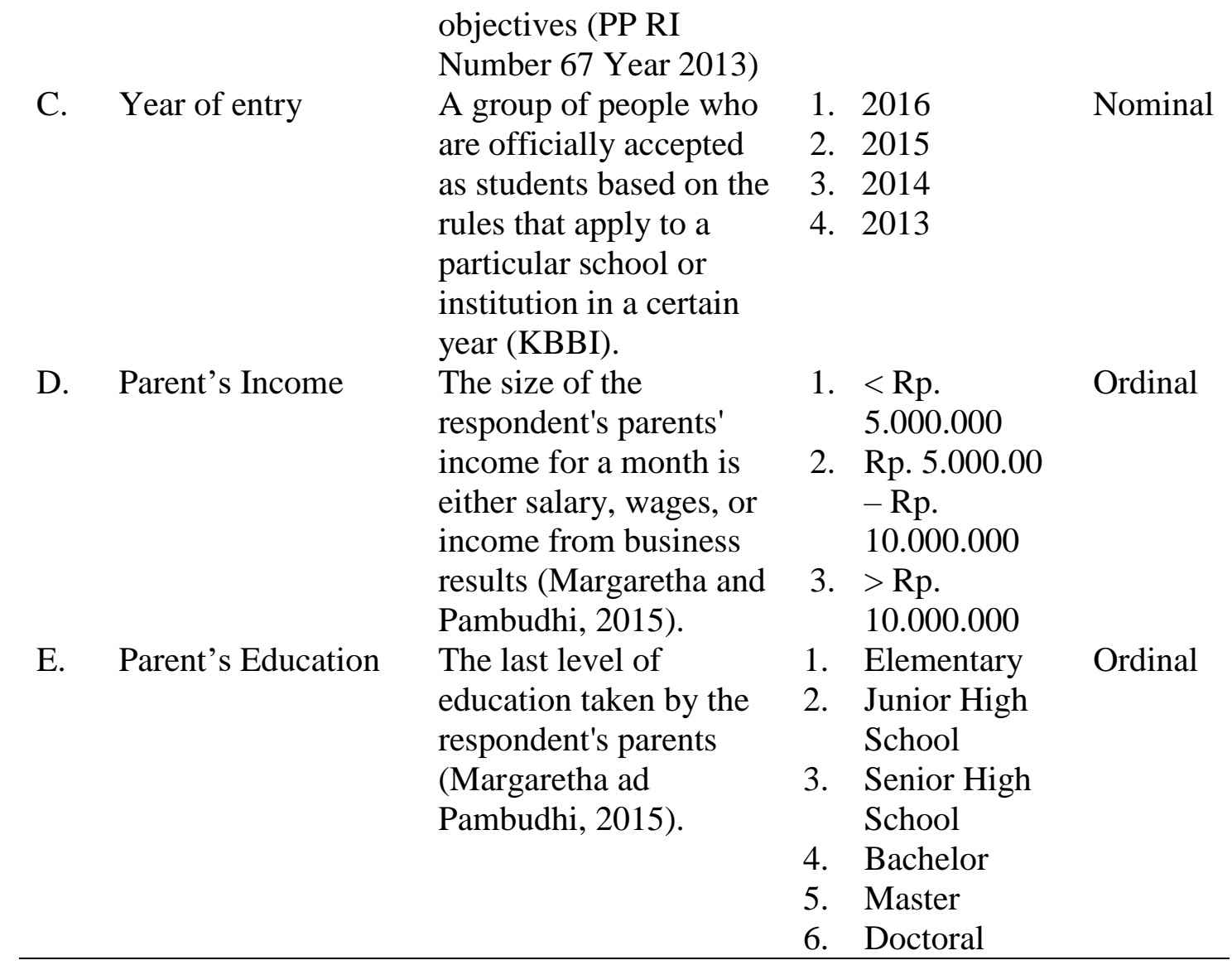

RESULT AND DISCUSSION

Multiple Regression Analysis
The hypothesis in this study was tested using multiple linear regression analysis with the following results:

Table 2. Result

\begin{tabular}{lccc}
\hline \multicolumn{1}{c}{ Variable } & \multicolumn{2}{c}{$\begin{array}{c}\text { Unstandardized } \\
\text { Coefficents }\end{array}$} & $\begin{array}{c}\text { Standardized } \\
\text { Coefficients }\end{array}$ \\
& B & $\begin{array}{c}\text { Std. } \\
\text { Error }\end{array}$ & Beta \\
\hline (Constant) & 0.641 & 0.046 & \\
Gender & -0.015 & 0.015 & 0.063 \\
Department & -0.007 & 0.010 & 0.062 \\
Year of entry & -0.022 & 0.007 & 0.179 \\
Parent's income & -0.008 & 0.014 & 0.051 \\
Parent's education & 0.006 & 0.009 & -0.044 \\
& & & \\
\hline
\end{tabular}

Source: Data Processed 
The regression equation is:

$$
\mathrm{Y}=0.641-0.015 \mathrm{X}_{1}-0.007 \mathrm{X}_{2}-0.022 \mathrm{X}_{3}-0.008 \mathrm{X}_{4}+0.006 \mathrm{X}_{5}
$$

\section{Hypothesis Test}

\section{Coefficient of Determination $\left(\mathbf{R}^{2}\right)$}

The following results are the coefficient of determination in this study:

Table 3. The coefficient of determination results $\left(R^{2}\right)$

\begin{tabular}{ccccc}
\hline Model & $\mathbf{R}$ & $\begin{array}{c}\mathbf{R} \\
\text { Square }\end{array}$ & $\begin{array}{c}\text { Adjusted R } \\
\text { Square }\end{array}$ & $\begin{array}{c}\text { Std. Error of the } \\
\text { Estimate }\end{array}$ \\
\hline 1 & 0.200 & 0.040 & 0.025 & 0.13414 \\
\hline
\end{tabular}

\section{Source: Data Processed}

The test results of the coefficient of determination in table 3 can be seen that $\mathrm{R}$ of 0.200 shows the correlation between the independent variables on the dependent variable is weak, because the value of $R$ does not approach 1. Adjusted R Square value of 0.025 which means that the dependent variable can be explained by the independent variables of $2.5 \%$, while the remaining $97.5 \%$ is explained by other independent variables outside the variables in this study.

F Test

Following are the results of the $\mathrm{F}$ test in this study:

Table 4. F Test Result

\begin{tabular}{|c|c|c|c|c|c|}
\hline Model & $\begin{array}{c}\text { Sum of } \\
\text { Squares }\end{array}$ & Df & $\begin{array}{l}\text { Mean } \\
\text { Square }\end{array}$ & $\mathbf{F}$ & Sig. \\
\hline 1 Regression & 0.245 & 5 & 0.049 & 2.726 & .020 \\
\hline Residual & 5.866 & 326 & 0.018 & & \\
\hline Total & 6.111 & 331 & & & \\
\hline
\end{tabular}

\section{Source: Data Processed}

From the results above, it can be seen that the calculated $F$ value is 2,276 and the significance is $0.020<0.05$. So it can be concluded that the variables of gender, department, year of entry, parent's income and parent's education simultaneously influence financial literacy. T Test

The results of the $t$ test in this study are as follows:

Table 5. T Test Result

\begin{tabular}{lc}
\hline Independent Variable & Sig. \\
\hline Gender $\left(\mathrm{X}_{1}\right)$ & 0.319 \\
Department $\left(\mathrm{X}_{2}\right)$ & 0.450 \\
Year of entry $\left(\mathrm{X}_{3}\right)$ & 0.001 \\
Parent's income $\left(\mathrm{X}_{4}\right)$ & 0.573 \\
Parent's education $\left(\mathrm{X}_{5}\right)$ & 0.473 \\
\hline \multicolumn{2}{c}{ Source $:$ Data Processed }
\end{tabular}

From the results of the $t$ test in the table it can be seen that the first, second, fourth and fifth hypotheses cannot be accepted, because the significance value of each variable is $0.319,0.450,0.537$ and 0.473 greater than 0.05 . As for the third hypothesis, the year entered can be 
accepted, because the significance value of 0.001 is smaller than 0.05 .

The first hypothesis in this study is to suspect the influence of gender on financial literacy in Andalas University Faculty of Economics students. From the results of this study it was found that gender had no effect on the financial literacy of Andalas Economics Faculty students because it had a significance value of 0.319 which was greater than 0.05 which meant the hypothesis was rejected. This result is different from the initial assumption that states that there is a gender influence on financial literacy. This happens because there are no restrictions to get information about financial matters and have the same opportunity to get information about financial matters, both of the sexes of men and women. In the Faculty of Economics itself, there is no difference between women and men to get the same information. The results of this study are supported by research conducted by Altintas (2011), Kaur, et. al. (2015), Nidar and Bestari (2012), and Shaari, et. al. (2013) which states that there is no gender effect on financial literacy.

The second hypothesis in this study is to suspect the influence of the department on financial literacy in Andalas University Faculty of Economics students. From the results of this study it was found that the department had no effect on the financial literacy of Andalas Economics Faculty students because it had a significance value of 0.450 which was greater than 0.05 which meant the hypothesis was rejected. This result is different from the initial assumption that states that there is an effect of the department on financial literacy. This occurs because economics students have received equitable information about financial literacy from each department in the Faculty of Economics. The existence of information or knowledge about finance in various courses applied at the Faculty of Economics makes it easy for each department to achieve the same financial literacy. The results of this study are supported by research conducted by Altintas (2011) which states there is no effect of the department on financial literacy.

The third hypothesis in this study is to suspect the influence of the entrance year on financial literacy in Andalas University Faculty of Economics students. From the results of this study it was found that the entrance year had an effect on the financial literacy of Andalas Faculty of Economics students because it had a significance value of 0.001 which was smaller than 0.05 which meant the hypothesis was accepted. This result is the same as the original assumption that states that the influence of the incoming year on financial literacy. This happens because more senior students get more information about financial literacy in each lecture compared to junior students. The results of this study are supported by research conducted by Shaari, et. al. (2013) which states the influence of the year entered the financial literacy.

The fourth hypothesis in this study is to suspect the effect of parent's income 
on financial literacy in Andalas University Faculty of Economics students. From the results of this study it was found that parent's income had no effect on the financial literacy of Andalas Economics Faculty students because it had a significance value of 0.573 which was greater than 0.05 which meant the hypothesis was rejected. This result is different from the initial assumption that states that there is an influence of parent's income on financial literacy. This can happen because parent's income constraints do not prevent students from obtaining information about finances and also each study program provides knowledge about financial literacy that is equitable. The results of this study are supported by research conducted by Kaur, et. al (2015) and Nidar and Bestari (2012) which state that there is no influence of parent's income on financial literacy.

The fifth hypothesis in this study is to suspect the influence of the level of

\section{CONCLUSSION}

The conclusion that can be drawn from the discussion above is;

1. Gender does not have a significant effect on financial literacy.

2. The department has no significant effect on financial literacy.

3. The year entered has a significant influence on financial literacy.

4. Parent's income does not have a significant effect on financial literacy. parent's education on financial literacy in students of the Faculty of Economics, Andalas University. From the results of this study it was found that the level of parent's education does not affect the financial literacy of Andalas Economics Faculty students because it has a significance value of 0.473 which is greater than 0.05 which means the hypothesis is rejected. This result is different from the initial assumption that states that there is an influence of the level of parent's education on financial literacy. This happens because every parent with various levels of education currently cares about education, so it is directly proportional to the increasing level of student financial literacy. The results of this study are supported by research conducted by Kaur, et. al. (2015), Margaretha and Pambudhi (2015), and Nidar and Bestari (2012) who stated that there was no influence of parent's education on financial literacy.

5. The education level of parents does not have a significant effect on financial literacy.

6. Gender, study program, year of entry, parent's income and parent's education simultaneously influence the level of financial literacy.

\section{SUGGESTION}

The findings in this study produce several implications, including the following: 
1. For students to continue to expand financial literacy and implement it well in their daily lives in order to be able to manage finances effectively in order to achieve financial prosperity.

2. For parents to continue to provide direction and guidance on finance for their children in order to enrich financial literacy and be correct in taking action regarding financial governance.

3. For lecturers to continue to provide various materials regarding financial literacy with various creative media, so that students can foster a sense of awareness about financial governance.

4. For the government and educational institutions to add or expand materials related to financial literacy to the students. This is done to support programs from the government in raising the level of financial literacy and being able to use financial management effectively, to achieve financial prosperity.

\section{REFERENCESS}

Afrianto, Dedy. 2016. Dalam 3 Tahun Literasi Keuangan Ditargetkan Naik $50 \%$ (online: http://economy.okezone.com/read/20 16/09/09/320/1485450/dalam-3tahun-literasi-keuangan-ditargetkannaik-50; diakses tanggal 10 Oktober 2016).

Almenberg, J. \& Dreber, A. 2015, "Gender, Stock Market Participation and Financial Literacy". Economic Letters. Elsevier B.V.

Altaf, N. 2014. "Measuring the Level of Financial Literacy Among Management Graduates" Journal of Research in Commerce \& Management. Central University of Kahsmir. Abhinav Publication.

Altintas, K.M. 2011. "The Dynamics of Financial Literacy within the Framework of Personal Finance: An Analysis Among Turkish University Students". African Journal of Business Management. Cankaya University.

Arora, S. \& Marwaha, K. 2013. "Financial Literacy Level and Awareness Regarding Stock Market”. Management and Labour Studies. SAGE Publication.

Bannier, C.E. \& Neubert, M. 2016. "Gender Differences in Financial Risk Taking: The Role of Financial Literacy and Risk Tolerance". Economic Letters. Guttenberg University Mainz. Elsevier B.V.

Driva, A., Luhrmann, M. \& Joachim, W. 2016. "Gender Differences and Stereotypes in Financial Literacy: Off to an Early Start". Economic Letters. Elsevier B.V.

Ghozali, Imam. 2006. Aplikasi Analisis Multivariate dengan Program SPSS. Cetakan Keempat. Semarang: Badan Penerbit Universitas Diponegoro.

Gulo, W. 2007. Metode Penelitian. Jakarta: Grasindo.

Hungu. 2007. Demografi Kesehatan Indonesia. Jakarta: Grasindo. 
Jannah. 2012. Metode Penelitian Kuantitatif. Jakarta: PT Raja Grafindo Persada.

Jorgensen, B. L. 2007. "Financial Literacy of College Students: Parental and Peer Influences".

Kaur, M., Vohra, T. \& Arora, R. 2015. "Financial Literacy among University Students: A Study of Guru Nanak Dev University, Amritsar, Punjab". Asia-Pacific Journal of Management. Guru Nanak Dev University. SAGE Publications.

KBBI Daring. (online: http://www.kbbi.kemendikbud.go.id/ entri/Generasi; diakses pada tanggal 28 Desember 2016).

Krishna, A., Sari, M. \& Rofaida, R. 2010. "Analisis Tingkat Literasi Keuangan di Kalangan Mahasiswa dan FaktorFaktor yang Mempengaruhinya Survey pada Mahasiswa Universitas Pendidikan Indonesia".

Mandell, L. 2008. "The Financial Literacy of Young American Adult: Results of the 2008 National jump Start Coalition Survey of High School Seniors and College Students".

Mandell, L. \& Klein, L. S. 2009. "The Impact of Financial Literacy Education on Subsequent Financial Behavior".

Margaretha, F. \& Pambudhi, R.F. 2015. "Tingkat Literasi Keuangan pada Mahasiswa S-1 Fakultas Ekonomi”.

Mouna, A \& Jarboui, A. 2015. "Financial Literacy and Portfolio
Diversification: An Observation from the Tunisian Stock Market". International Journal of Banking Marketing. University of Sfax FSEGES. Emerald Group Publishing Limited.

Nidar, S.R. \& Bestari, S, 2012. "Personal Financial Literacy Among University Students (Case Study at Padjadjaran University Students, Bandung, Indonesia)". World Journal of Social Sciences 2 (4). July.

Otoritas Jasa Keuangan. 2013. Literasi Keuangan (online: http://www.ojk.go.id/id/kanal/edukas i-dan-perlindungan konsumen/Pages/Literasi-

Keuangan.aspx; diakses tanggal 10 Oktober 2016).

Potrich, A.C.G., Vieira, K.M. \& Kirch, M.A. 2015. "Determinants of Financial Literacy: Analysis of the Influence of Socioeconomic and Demographic Variables".

Sekaran, Uma. 2006. Metodologi Penelitian untuk Bisnis. Buku 1 dan 2. Jakarta: Salemba Empat.

Shaari, N.A., Hasan, N.B., Mohamed, R.K.M.H. \& Sabri, M.A.J.M. 2013. "Financial Literacy: A Study Among the University Students". Interdisciplinary Journal of Conyemporary Research in Business.

Sugiyono. 2015. Metode Penelitian Manajemen. Bandung: Alfabeta. 